Tadeusz UHL ${ }^{*}$, Zbigniew ŚLIWA*, Sławomir GRZESICA*

\title{
A MODEL OF A SMALL SIZE SOLAR-HYDROGEN POWER INSTALLATION
}

\begin{abstract}
SUMMARY
This paper describes a miniaturized model of a small size solar-hydrogen power installation with a reserve electricity source in the form of a fuel cell. The cell was powered with hydrogen generated in the electrolyzer in time periods when the photovoltaic panel works in suitable insolation conditions. Hydrogen was stored in a special tank, containing hydride releasing hydrogen in convertible reactions. The tests shown were performed in the summer and in various weather conditions. Conclusions confirmed the usefulness of the model for the design of full sized installations dedicated to summer cottages and similar objects. Modifications of the model were proposed with the aim to obtain quantitative test results needed for designing more efficient installations.
\end{abstract}

Keywords: photovoltaics, energy storage, hydrogen, fuel cell, electrolyse

\section{MODEL MAEEJ ELEKTROWNI SEONECZNO-WODOROWEJ}

$W$ artykule przedstawiono miniaturowy model matej elektrowni stoneczno-wodorowej, w której zastosowano rezerwowe źródło zasilania pradem elektrycznym $w$ postaci ogniwa paliwowego. Ogniwo zasilane jest wodorem wytwarzanym $w$ elektrolizerze $w$ okresach pracy ogniw fotowoltaicznych przy wystarczajacych warunkach nastonecznienia. Wodór magazynowany jest $w$ specjalnym zbiorniku zawierajacym wodorki uwalniajace wodór $w$ procesie odwracalnym. Przedstawiono przebieg testów, którym poddano model $w$ okresie letnim, przy zróżnicowanych warunkach pogodowych. We wnioskach potwierdzono przydatność modelu przy projektowaniu petnowymiarowych instalacji dla obiektów letniskowych. Zaproponowano również jego modyfikacje w celu uzyskania ilościowych wyników testów, przydatnych przy projektowaniu bardziej wydajnych instalacji.

Stowa kluczowe: fotowoltaika, magazyn energii, wodór, ogniwo paliwowe, elektroliza

\section{INTRODUCTION}

When designing sun-based power generation systems it is crucial to consider a reserve energy source for low insolation periods. In the case of grid connected installations, the problem does not exist. On the contrary, when power network is not accessible, batteries are in use. They are charged when solar conditions are good enough (Klugmann-Radziemska 2010, Gałusza and Paruch (eds.) 2008).

The amount of energy stored in this way depends on the capacity of the batteries and the level they are currently charged to. If there is a lack of solar light for a relatively long period of time, resources may occur insufficient. This is not only the case of night time, but also the situation when solar radiation is too weak for PV panels to generate the electric current of parameters sufficient for the battery to charge. Energy produced in such conditions can not be stored and utilized. On the other hand, if the period of good solar conditions for PV generation is very long, a significant amount of energy can be lost because of small battery capacity (Planning 2005).

The attempt to solve the above problem is to use another manner of energy storage: in the form of hydrogen, produced in the electrolyse process, in periods of good weather with sufficient insolation. The suggested system consist of two main subsystems: electrolyzer and fuel cell. The latter generates electric power from stored hydrogen during periods of low insolation level (Surygała 2008).
With the aim to test the performance of so configured system it was decided to build a model of a miniature solar-hydrogen power station and test it in typical exploitation conditions. It was assumed, that the power station will work only in the summer when the insolation is the best. It could serve as a power source in summer cottages and similar objects.

\section{DESCRIPTION OF THE MODEL}

The model consists of following elements:

- photovoltaic panel,

- electrolyzer,

- hydrogen dryer,

- tank for hydrogen storage,

- fuel cell,

- battery,

- voltage converters,

- PLC controller.

Figure 1 shows the functional graph of the model. Block arrows $\longrightarrow$ symbolize the flow of energy media: electric current and hydrogen, when line arrows $\longrightarrow$ represent control signals in the system. Measurement chains of voltage on the PV panel and the battery are marked with dash lines ----------.

* AGH University of Science and Technology, Faculty of Mechanical Engineering and Robotics, Department of Robotics and Mechatronics, al. A. Mickiewicza 30, 30-059 Krakow, Poland; corresponding author Zbigniew Sliwa, zsliwa@agh.edu.pl 


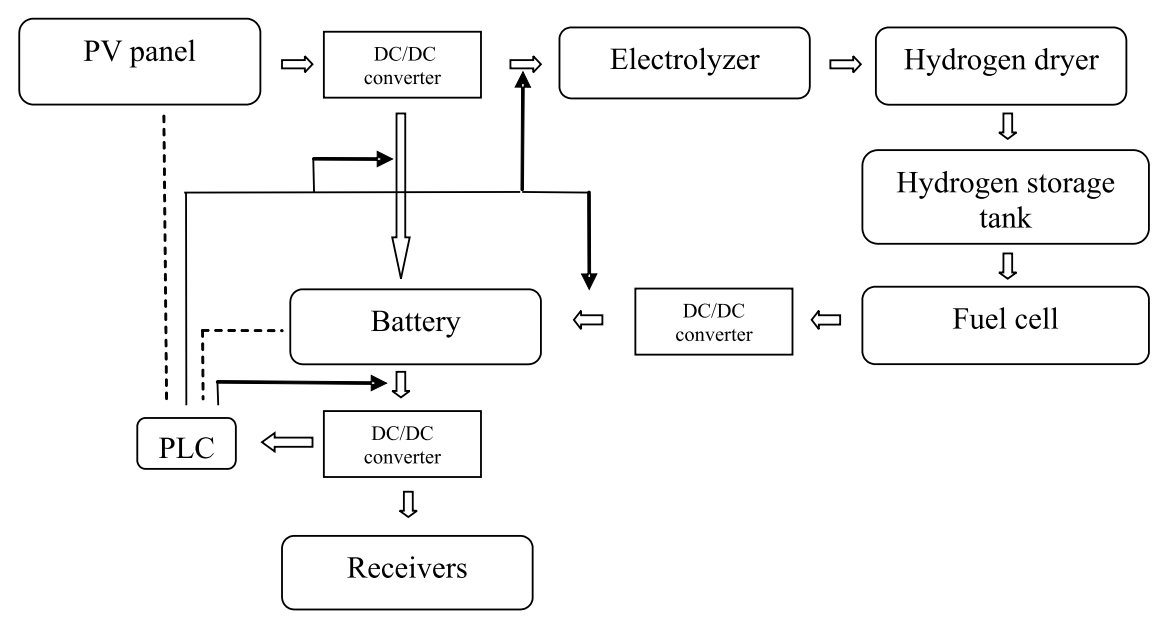

Fig. 1. Functional graph of the solar-hydrogen power station test model

\section{ELEMENTS OF THE MODEL}

Photovoltaic panel: PowerFilm R15-2000. Manufactured of amorphous silicon, in thin film technology on flexible plastic substrate (silicon based) (http://www.intech.eu/ oferta.html).

Technical specification:

- Voltage MPP: $15.4 \mathrm{~V}$,

- current MPP: $1.35 \mathrm{~A}$,

- power MPP: $21 \mathrm{~W}$,

- weight: $0.88 \mathrm{~kg}$,

- protective diode.

Electrolyzer PEM with polymer membrane, fed with distilled water (http://www.hydrogenics.com/).

Technical parameters (Fig. 2):

- area of electrodes: $2 \times 16 \mathrm{~cm}^{2}$,

- input power: $15 \mathrm{~W}(4 \mathrm{~V})$,
- voltage limits: $3.0-4.0 \mathrm{~V} \mathrm{DC}$,

- current limits: 0-4.0 A DC,

- hydrogen production: $65 \mathrm{~cm}^{3} / \mathrm{min}$.

Hydrogen storage, consisting of a dryer and tank. The dryer protects the fuel cell against defects caused by moisturised hydrogen. It is build as a pipe filled with plastic pellets. The tank's volume is $10000 \mathrm{~cm}^{3}$. It contains hydride releasing hydrogen in convertible reactions (Surygała 2008).

Fuel cell EcoFC3 manufactured by $\mathrm{H}_{2}$ Economy for presentation and research purposes. It is equipped with a polymer membrane PEM. It is built as a battery of three single cells in serial connection.

Technical parameters:

- generated voltage: $3 \times 0.9 \mathrm{~V}$,

- nominal power (of the battery): $10 \mathrm{~W}(1.8 \mathrm{~V})$,

- recommended pressure of hydrogen and oxygen supplies: 1 bar.

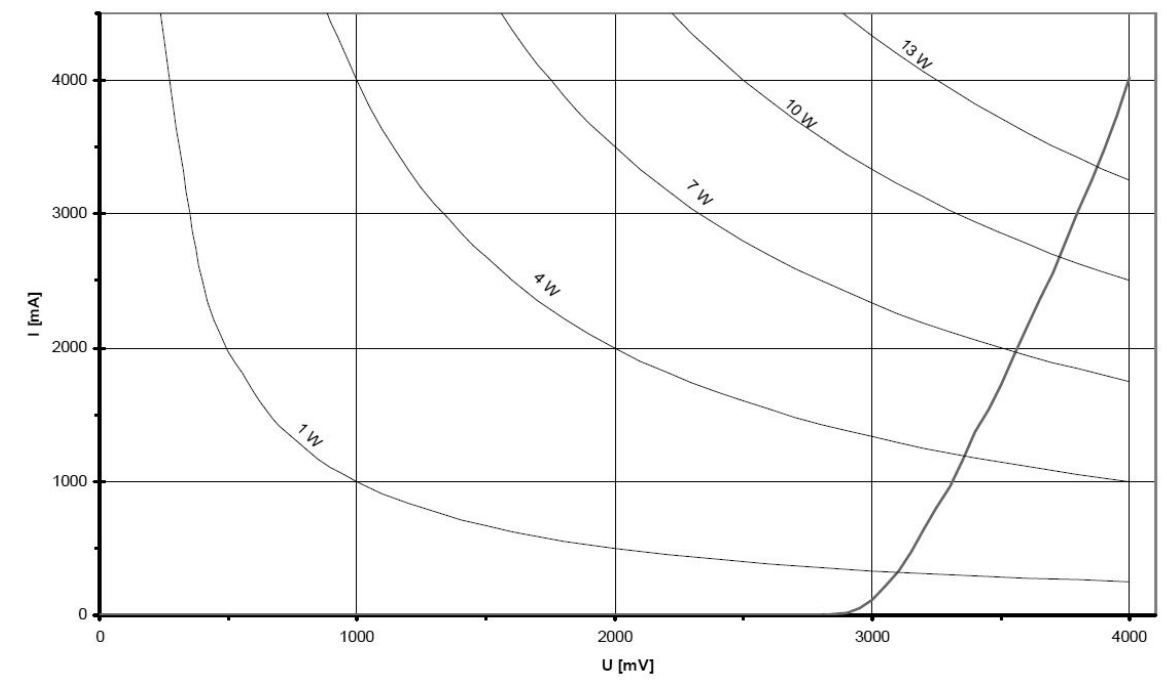

Fig. 2. Current - voltage characteristic of the electrolyzer (http://www.hydrogenics.com/) 
PLC controller Siemens LOGO! 12/24RC. Universal device for home use, in home automation, but also for industrial applications, agriculture and machine protection (Logo).

Technical parameters:

- analogue inputs: 4 ,

- relay outputs: 4 ,

- minimal voltage in operation: $10.8 \mathrm{~V}$,

- measured voltage range on analogue inputs: 0-10 V (obligatory use of voltage dividers).

Battery AGM TP12-7, maintenance-free. Manufactured in Absorber Glass Mat (AGM) technology - whole electrolyte is absorbed in glass-fibre separators of huge porosity located between plates. AMG batteries are characterized by low internal resistance which gives higher voltage on clamps and longer operation time, especially when discharged by high currents.
Technical parameters:

- nominal voltage: $12 \mathrm{~V}$,

- capacity: $7 \mathrm{Ah}$,

- charging and discharging characteristics shown in Figure 3 .

DC/DC step-up converter adjusting the fuel cell voltage to the needs of the battery charging process.

Technical parameters:

- efficiency up to $90 \%$,

- output voltage: $15 \mathrm{~V}$,

- output nominal current $0.9 \mathrm{~A}$,

- maximum output current $1.0 \mathrm{~A}$,

- thermal and current protection.

\section{THE CONTROL ALGORITHM}

The block diagram of the solar-hydrogen power station model control algorithm is presented in the Figure 4.

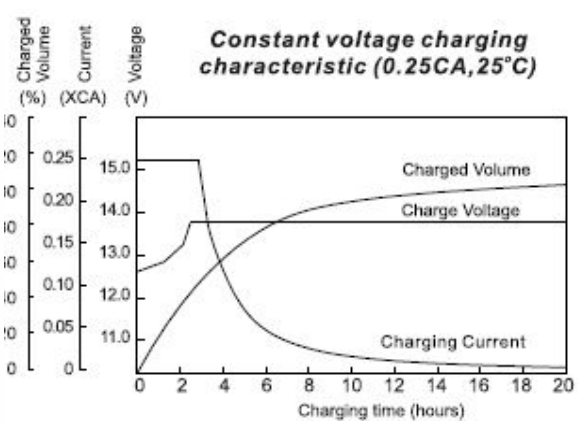

Fig. 3. Charging and discharging the characteristics of the AMG battery (Planning 2005)

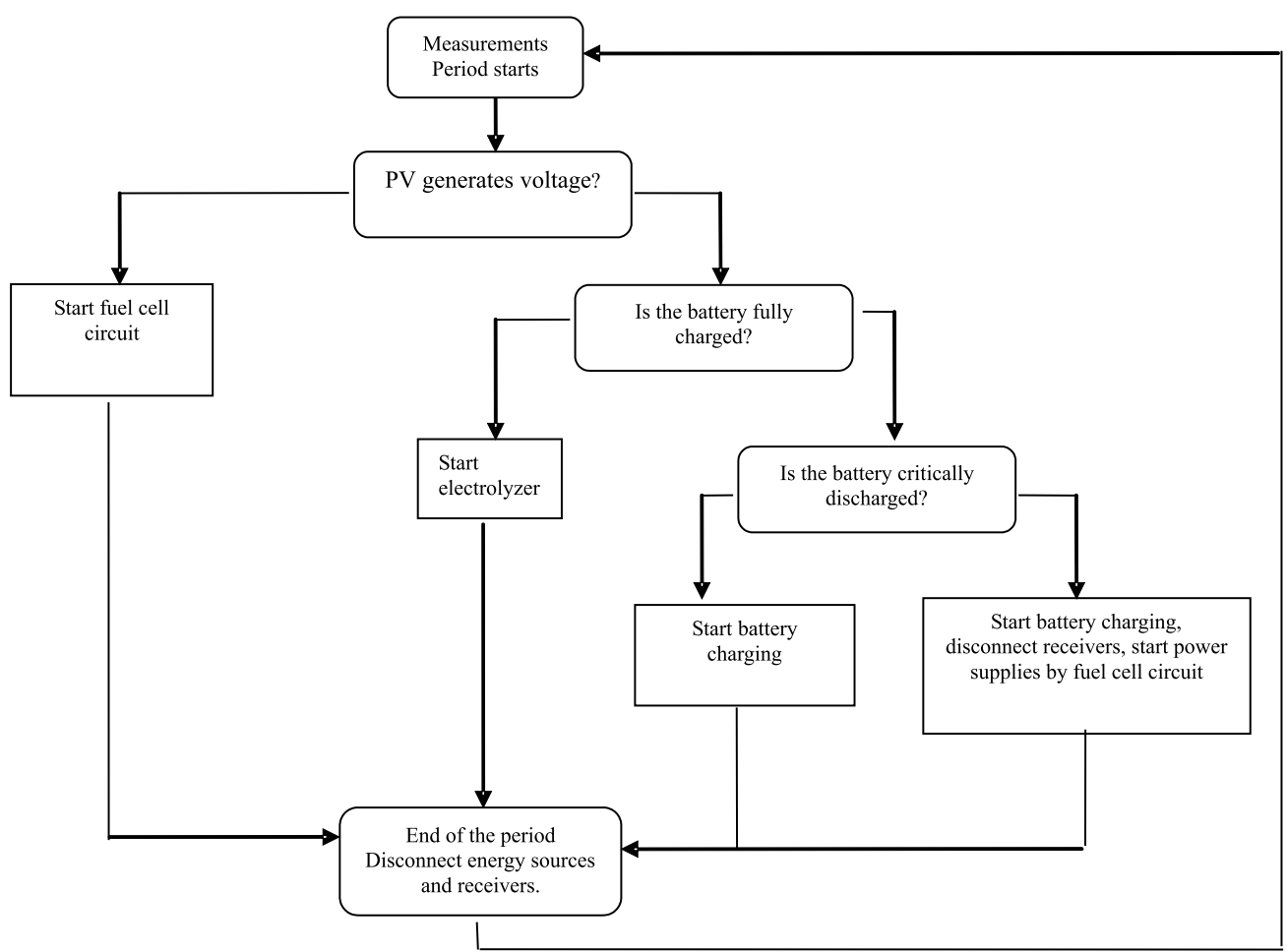

Fig. 4. Solar-hydrogen power station model control algorithm 
Because the voltage measurement of the battery in the state disconnected from the receivers was needed, periodic charging was applied with the voltage measurement at the beginning of each period. The assumed time of the period was 30 minutes and 1 second. The measurement on the clamps of the battery and PV panel is done during the first second of the period. The battery is disconnected from the system during that time.

There are several functional modes of the model during the single period, depending on the voltage value measured for the PV panel and the charging state of the battery:

1. The PV voltage is below the given threshold which means that the insolation is not sufficient (nightime, cloudy day etc.). The fuel cell source will be switched on.

2. PV generates sufficient voltage and the battery is fully charged. Power from PV is used for hydrogen production in the electrolyzer.

3. PV panel provides sufficient voltage, battery is not fully charged. PV charges the battery.

4. PV panel provides sufficient voltage, the battery in critically discharged. The whole power from PV and fuel cell is utilized for the battery charging.

\section{THE PERFORMANCE TEST OF THE SOLAR-HYDROGEN POWER STATION MODEL}

The test was run between 16th July and the 14th of August 2010. Daily from 10.00 to 17.00 five voltage measurements on the PV clamps were done. The average voltage value was calculated for each day. Results are shown in Figure 5 .

The figure shows intense changes in weather conditions during the test period. In days 18-19 as well as 24-28 of July is used to be cloudy with showers. Also, at the beginning of August days were rather cloudy. In the whole period the number of sunny days was small.

Two subsequent graphs were prepared for extreme weather conditions, which occurred during the testing. They show the variability of voltage on the PV panel and battery clamps during the cloudy day (Fig. 6) and the sunny day (Fig. 7). Marks visible below the time axis of both graphs allow us to determine changes of model functional modes during a day.

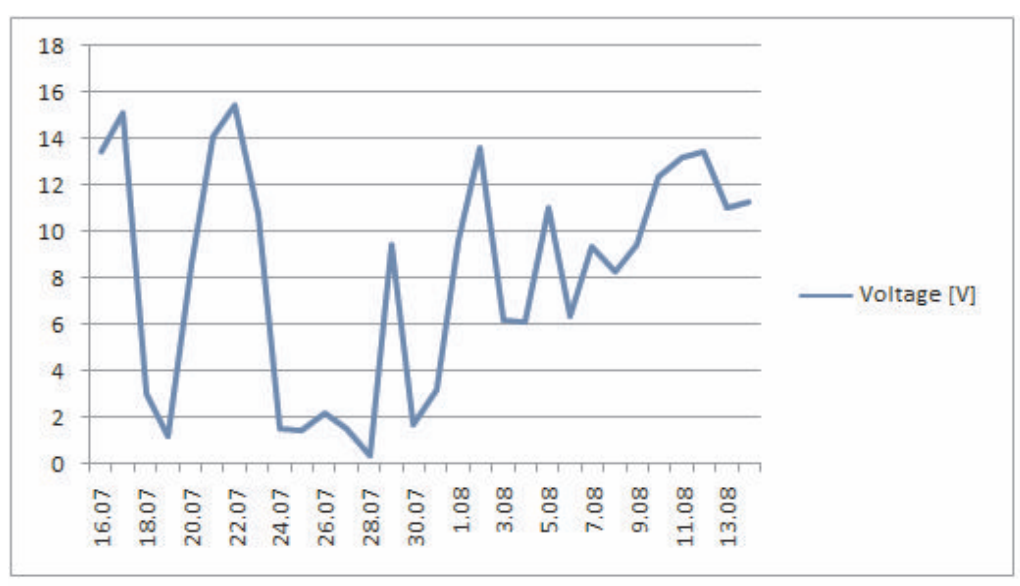

Fig. 5. PV panel - average voltage values obtained during the test period

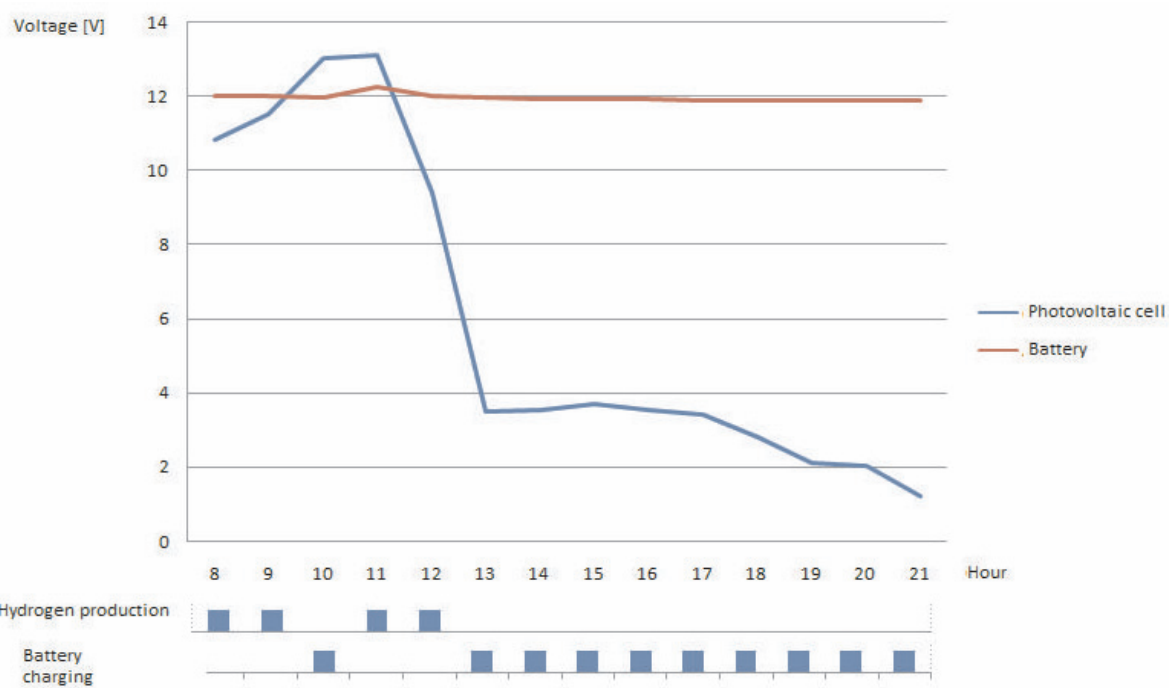

Fig. 6. Voltage of PV panel (blue line) and the battery (red line) during cloudy day (time in hours). In rows below time axis: hydrogen production and battery charging 


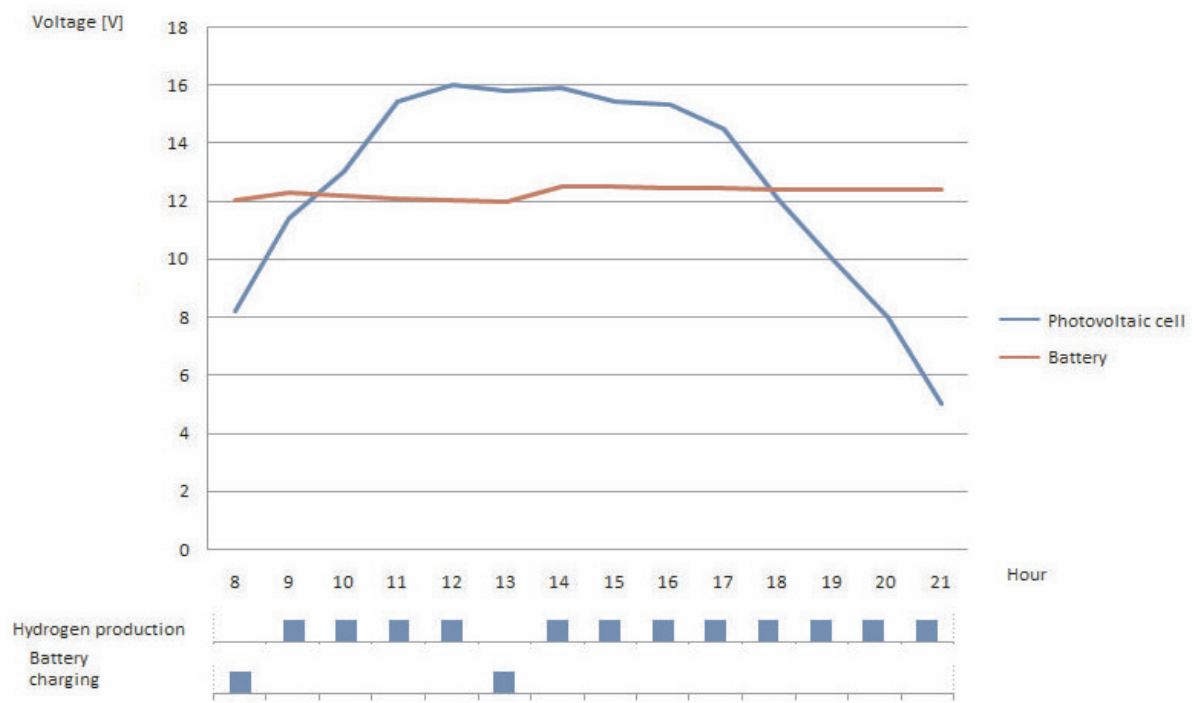

Fig. 7. Voltage of PV panel (blue line) and the battery (red line) during the sunny day (time in hours). In rows below the time axis: hydrogen production and battery charging

On the cloudy day, after a sunny morning, the weather got significantly worse, resulting in the PV panel voltage falling rdown. Hydrogen generation was suspended because the battery was partially discharged. In the control algorithm the battery charging has the priority before hydrogen generation. After one charging period the system returned to the hydrogen generation mode and remained in this state for two subsequent periods up to about twelve o'clock. When the weather got worse, the battery simultaneously became discharged. As a result, the system was again switched to the battery charging mode. Because the insolation was not sufficient, the system remained in this mode for the rest of the day and did not return to hydrogen generation. At the end of a day the battery was not fully charged.

On the sunny day the system started its activity from the battery charging for one period. Afterwards, hydrogen generation started and continued for four subsequent periods. It stopped when the battery voltage fell down, as a result of partial battery discharge. One charging period was enough to retain the system in a hydrogen generating mode for the rest of a day.

\section{CONCLUSIONS}

The low cost model of a small size solar-hydrogen power installation was suitable for valuable tests preceding the designing works on a full scale system dedicated to summer recreation buildings. Investigations conducted up to now gave the basis for some conclusions on the influence of weather conditions on system performance. Because the scale rate of the model was significantly large the results are of qualitative rather than of quantitative character.

1. The control algorithm for the system of the given structure shows big sensitivity on time-changing insolation even during the summer 30 days of July and August. Results of the exemplary cloudy day have shown no hydrogen production though the majority of day-time.
The system remained in a battery charging mode when PV panel voltage was too low to obtain a significant charge level of the battery.

2. By modifying the control algorithm as well as the appropriate dimensioning of the PV panel and electrolyzer resulting power could be better utilized for hydrogen production, even in weak insolation conditions.

3. The power of the PV panels should be much bigger to make possible simultaneous the generation of energy for both current consumption and hydrogen production.

4. It could be useful to build a model of a scale suitable for the quantitative estimation of energy obtained from the system in design.

5. Tests should be conducted for a whole year to verify system usefulness also for buildings of the permanent use. The obtained data would be valuable in technical and economical calculations of the full scale system based on PV and hydrogen cell energy sources.

Continuation of work on the model and its further modifications and adjustments seems to be interesting and worth recommending. It can lead to obtain the valuable tool for designs of systems utilizing promising technologies like PV as well as fuel cells and electrolyzers.

\section{References}

Gałusza M., Paruch J. (Eds) 2008, Odnawialne i niekonwencjonalne źródla energii - poradnik, Wydawnictwo Tarbonus, Kraków-Tarnobrzeg.

Klugmann-Radziemska E. 2010, Fotowoltaika w teorii i praktyce, Wydawnictwo PWN, Legionowo.

Logo! Siemens - podręcznik, wydanie 9.

Planning and installing photovoltaic systems, A guide for installers, architects and engineers, James \& James, 2005.

Surygała J. 2008, Wodór jako paliwo, Wydawnictwo Naukowo-Techniczne, Warszawa.

http://www.hydrogenics.com/

http://www.intech.eu/oferta.html 
